\title{
HUBUNGAN ANTARA WILAYAH KENDALI DAN TANGGUNG JAWAB PERSONAL DENGAN INTENSI PRO-LINGKUNGAN
}

\author{
Ahsanul Akhsan Dasi ${ }^{1}$, Mieke Miarsyah, \& Rusdi \\ Jurusan Pendidikan Biologi, Fakultas Matematika dan Ilmu Pengetahuan Alam, Universitas Negeri Jakarta, \\ Kampus A, Jakarta Timur 13220, Indonesia
}

Korespondensi:

Ie-mail: ahsanulakhsandasi@gmail.com

\begin{abstract}
Locus of control is a belief in oneself as a center of control that directs a person's behavior to move within him towards the outside of them. Personal responsibility can be defined as individuals who deal with actions that will affect others. The role of personal responsibility is important to change students' proenvironmental intention. This study aims to analyze the relationship between locus of control and personal responsibility with pro-environmental intention at SMAN 8 Makassar City. Participants for the study were 120 students from 11th grade. This study used a quantitative approach with a descriptive method of correlation techniques, using survey data. The results showed a positive relationship between locus of control and personal responsibility with pro-environmental intention.
\end{abstract}

Article history:

Received 14 December 2018

Received in revised form 16 January 2019

Accepted 20 January 2019

Available online 21 April 2019

\section{Keywords:}

locus of control;

personal responsibility;

pro-environmental intention

\begin{abstract}
Abstrak - Wilayah kendali merupakan sesuatu yang menuntun keinginan seseorang untuk bertindak melakukan sesuatu. Tanggung jawab pribadi adalah batasan yang dipilih sendiri oleh individu yang berkaitan dengan mengambil tindakan yang akan memengaruhi orang lain. Peran tanggung jawab pribadi sangat penting untuk mengubah intensi prolingkungan seseorang. Penelitian ini bertujuan untuk menganalisis hubungan antara wilayah kendali dan tanggung jawab pribadi dengan intensi pro-lingkungan di SMAN 8 Kota Makassar. Jumlah responden terdiri dari 120 siswa dari kelas XI. Penelitian ini menggunakan pendekatan kuantitatif dengan metode deskriptif teknik korelasi berdasarkan data survei. Hasil analisis menunjukkan bahwa terdapat hubungan positif antara wilayah kendali dan tanggung jawab personal dengan intensi pro lingkungan.
\end{abstract}

Kata Kunci: wilayah kendali; tanggung jawab pribadi; intensi pro-lingkungan 


\section{PENDAHULUAN}

Perubahan dalam ekosistem disebabkan oleh aktivitas manusia, perubahan iklim, perubahan habitat (perubahan penggunaan lahan dan penyesuaian fisik sumber daya alam), perubahan populasi, eksploitasi berlebihan, perubahan teknologi, dan polusi (Keshavarz \& Karami, 2016). Berbagai masalah lingkungan menimbulkan ancaman bagi lingkungan, di antaranya pemanasan global, pencemaran udara perkotaan, kekurangan air, kebisingan lingkungan, dan hilangnya keanekaragaman hayati. Persoalan lingkungan yang selalu menjadi isu besar di hampir seluruh wilayah perkotaan di Indonesia adalah masalah sampah. Permasalahan sampah disebabkan kurangnya kepedulian masyarakat yang di antaranya ditunjukkan dengan membuang sampah sembarangan atau keengganan untuk membuang sampah pada tempat yang sudah disediakan. Perilaku yang buruk ini seringkali menyebabkan bencana di musim hujan karena drainase tersumbat sampah sehingga terjadi banjir (Wibisono \& Dewi, 2014). Banyak masalah ini berakar pada perilaku manusia dan dengan demikian dapat dikelola dengan mengubah perilaku yang relevan sehingga dapat mengurangi dampak lingkungannya (Steg \& Vlek, 2009)

Penyelesaian masalah terhadap lingkungan dapat dilakukan oleh komponen masyarakat maupun secara pribadi. Salah satu upaya yang dapat dilakukan untuk menyelesaikan masalah lingkungan yaitu dengan menumbuhkan keinginan untuk peduli terhadap lingkungan. Hines, Hungerford, dan Tomera (1987) mengembangkan model perilaku bertanggung jawab lingkungan. Dalam model mereka, keinginan untuk peduli terhadap lingkungan salah satunya dipengaruhi oleh faktor kepribadian, yaitu wilayah kendali (locus of control) dan tanggung jawab pribadi (personal responsibility) (Pan, Chou, Morrison, Huang, \& Lin, 2018). Model yang menggambarkan hubungan antara wilayah kendali dan tanggung jawab pribadi dengan keinginan untuk bertindak dapat dilihat pada Figur 1 berikut.

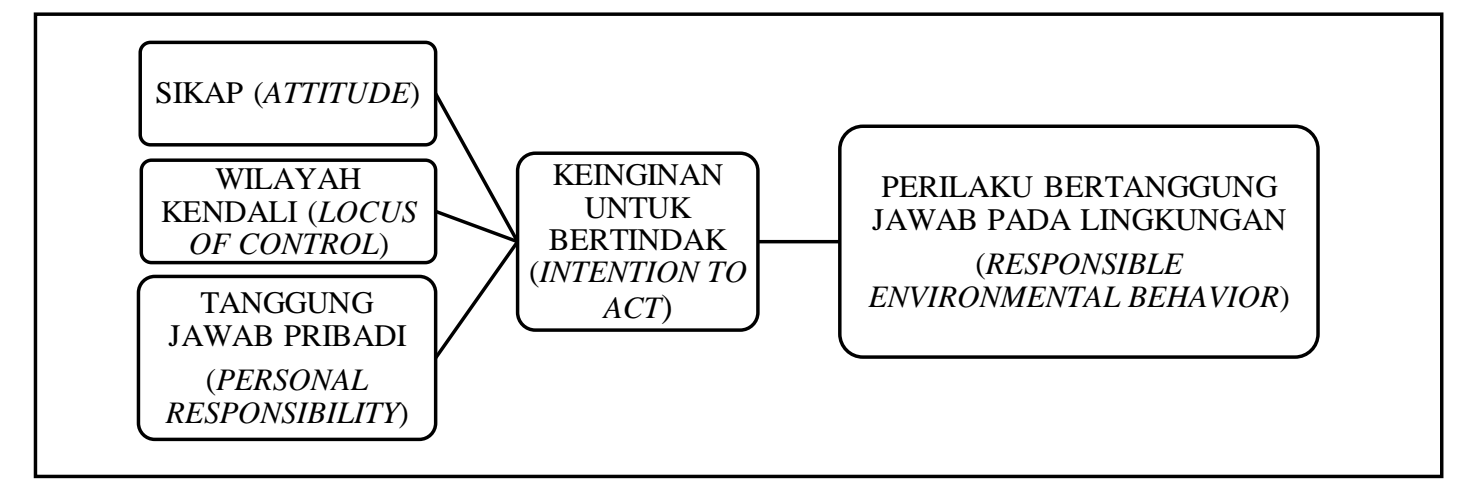

Figur 1. Model Perilaku Bertanggung jawab Lingkungan Hines (Sumber: Pan dkk., 2018) 
Masalah pembentukan wilayah kendali dan tanggung jawab pribadi siswa terhadap lingkungan sangat penting karena kelangsungannya didasarkan pada keyakinan bahwa hasil yang didapatkan berasal dari usaha pada individu itu sendiri untuk bertanggung jawab terhadap masalah lingkungan dan mengubah praktik sehari-hari mereka untuk mengurangi konsekuensi negatif (Slavoljub, Zivkovic, Sladjana, Dragica, \& Zorica, 2015). Wilayah kendali dan tanggung jawab pribadi merupakan suatu kesatuan yang saling melengkapi. Penelitian-penelitian sebelumnya hanya menampilkan satu sisi faktor kepribadian seseorang. Bukan hanya wilayah kendali, namun tanggung jawab pribadi juga harus dimiliki siswa sejak dini demi mempunyai keinginan untuk peduli terhadap lingkungan. Berdasarkan pernyataan tersebut, peran wilayah kendali dan tanggung jawab pribadi untuk menumbuhkan keinginan bertindak sangatlah penting karena dapat memengaruhi perilaku bertangggung jawab siswa terhadap lingkungan. Dengan demikian, dapat dikatakan bahwa wilayah kendali dan tanggung jawab pribadi berhubungan dengan keinginan siswa untuk bertindak terhadap lingkungan.

\section{Intensi Pro-Lingkungan (Pro-Environmental Intention)}

Keinginan didefinisikan sebagai dimensi kemungkinan seseorang yang menghubungkan dirinya dengan perilakunya sendiri. Keinginan untuk bertindak (intention to act) mengacu pada kemungkinan subjektif seseorang bahwa dia akan melakukan beberapa tindakan (Fishbein \& Ajzen, 2011). Intensi adalah niat untuk melakukan dan terus melakukan perilaku tertentu (Ramdhani, 2011).

Keinginan atau intensi didefinisikan sebagai rencana sadar seseorang untuk melakukan perilaku tertentu atau sebagai penilaian tentang perilakunya. Keinginan diperkenalkan sebagai komponen mediator antara sikap dan perilaku, yaitu sikap melayani untuk mengarahkan keinginan yang pada gilirannya memengaruhi perilaku. Keinginan untuk bertindak menjadi indikator sejauh mana seseorang akan bersedia melakukan sesuatu (Ferraz, Buhamra, Laroche, \& Veloso, 2017). Keinginan untuk bertindak didefinisikan sebagai persepsi subjektif seseorang tentang probabilitas bahwa dia akan melakukan perilaku yang dimaksud. Persepsi individu terhadap tekanan sosial membuatnya melakukan atau tidak melakukan perilaku dipengaruhi oleh orang, kelompok, atau hal yang dia pedulikan (Arttachariya, 2009).

Intensi pro-lingkungan (pro-environmental intention) merupakan kecenderungan perilaku seseorang tentang konsekuensi yang merugikan dari masalah lingkungan dan keinginan mereka 
untuk melakukan perilaku pro-lingkungan dalam upaya untuk mengantisipasi efek negatif dari masalah lingkungan dan rasa tanggung jawab untuk lingkungan tersebut (Henriksson, 2017).

\section{Wilayah Kendali (Locus of Control)}

Wilayah kendali merupakan perilaku stabil yang ada pada diri seseorang, yang berkaitan dengan kepercayaan mengenai berhasil atau gagalnya seseorang untuk melakukan sesuatu, di mana persepsi tersebut dipengaruhi oleh perilakunya sendiri atau faktor luar dirinya (Rucas \& Miller, 2013). Wilayah kendali memiliki kecenderungan, yaitu seorang individu percaya hasil usahanya berasal dari perilakunya atau dikendalikan oleh kekuatan eksternal, seperti: takdir, keberuntungan, kesempatan atau lainnya. Mereka yang memiliki wilayah kendali internal merasakan hasil dari kejadian bergantung pada tindakan mereka sendiri, sedangkan mereka yang memiliki wilayah kendali eksternal merasakan hasil dari kejadian bergantung dengan faktor eksternal (Erkan, 2015).

Wilayah kendali juga dapat dikatakan sebagai sebuah keyakinan seseorang terhadap penyebab keberhasilan dan kegagalan yang dialaminya. Dalam hubungannya dengan keinginan untuk bertindak terhadap lingkungan, wilayah kendali merupakan prediktor penting dalam keinginan untuk bertindak dan memiliki efek langsung yang substansial pada sikap yang memengaruhi keinginan siswa untuk bertindak terhadap lingkungan. Berdasarkan penelitian Yang, Lin, dan Liu (2016), wilayah kendali berhubungan dengan keinginan siswa untuk bertindak terhadap lingkungan. Berdasarkan keterangan tersebut, wilayah kendali merupakan salah satu faktor kepribadian yang menentukan keinginan siswa untuk bertindak terhadap lingkungan.

\section{Tanggung Jawab Pribadi (Personal Responsibility)}

Tanggung jawab pribadi dipahami sebagai kesediaan menerima pertanggungjawaban atas tindakannya sendiri dengan mempertimbangkan tindakan dan konsekuensi yang dihasilkan (Mergler \& Patton, 2007). Tanggung jawab pribadi merupakan kemampuan untuk mengatur pikiran, perasaan, dan perilaku sendiri bersama dengan kesediaan untuk bertanggung jawab atas pilihan yang dibuat (Mergler, Spencer, \& Patton, 2008). Tanggung jawab pribadi didefinisikan sebagai keyakinan bahwa seseorang adalah penguasa kehidupannya, menyadari pilihan dan tujuannya, serta bersedia menuntut pertanggungjawaban atas perilakunya dan mendapatkan konsekuensinya (Mergler \& Shield, 2016). 


\section{Tujuan Penelitian}

Berdasarkan pemaparan sebelumnya, wilayah kendali dan tanggung jawab pribadi merupakan faktor kepribadian yang memengaruhi keinginan siswa untuk bertindak terhadap lingkungan. Oleh karena itu, diperlukan adanya penelitian mengenai hubungan antara wilayah kendali dan tanggung jawab pribadi terhadap keinginan untuk bertindak terhadap lingkungan atau disebut sebagai intensi pro-lingkungan.

\section{METODE}

\section{Partisipan}

Partisipan penelitian ini adalah seluruh siswa Kelas XI SMAN di Kota Makassar. Pengambilan sampel dilakukan dengan beberapa langkah. Pertama, peneliti memilih salah satu SMAN tersebut dengan cara accidental sampling, yaitu dengan memilih salah satu sekolah dari seluruh sekolah di kota Makassar secara acak dan terpilih SMAN 8 Kota Makassar sebagai tempat penelitian. Selanjutnya, peneliti menetapkan siswa XI MIPA sebagai objek penelitian dengan metode purposive sampling dengan alasan kelas XI MIPA sudah menerima materi tentang pencemaran lingkungan. Lalu, dari lima kelas XI MIPA, peneliti memilih empat kelas sebagai objek dalam penelitian. Satu kelas digunakan untuk uji coba instrumen. Jumlah sampel terdiri 120 siswa. Pengumpulan data dilakukan menggunakan kuesioner.

\section{Desain}

Penelitian ini menggunakan pendekatan kuantitatif dengan metode deskriptif teknik korelasi untuk menghubungkan ketiga variabel, yaitu wilayah kendali (variabel pertama), tanggung jawab pribadi (variabel kedua), dan intensi pro-lingkungan (variabel ketiga).

\section{Prosedur}

Penelitian dilakukan dengan menggunakan instrumen non-tes berupa kuesioner. Hasil kuesioner tentang wilayah kendali dan tanggung jawab pribadi akan dihubungkan dengan hasil kuesioner tentang intensi pro-lingkungan siswa. 


\section{Instrumen}

Perolehan data tentang wilayah kendali, tanggung jawab pribadi, dan intensi pro-lingkungan dilakukan dengan menggunakan kuesioner.

Instrumen pertama menggunakan kuesioner wilayah kendali yang mencakup wilayah kendali internal dan eksternal siswa. Kuesioner wilayah kendali diukur dengan instrumen dari Rotter (1966), yaitu instrumen yang terdiri dari 29 pasang butir pernyataan, di mana setiap butir memiliki dua pilihan kalimat. Siswa memilih salah satu pernyataan dari setiap pasangan yang siswa percaya lebih kuat. Uji coba terhadap 30 partisipan dilakukan dengan kriteria yang sesuai dengan karakteristik penelitian. Berdasarkan hasil dari uji coba tersebut, ditemukan bahwa nilai reliabilitas instrumen wilayah kendali dengan menggunakan KR-20 sebesar .76.

Instrumen kedua menggunakan kuesioner tentang tanggung jawab pribadi berupa skala sikap yang akan mencirikan tanggung jawab pribadi siswa. Dimensi tanggung jawab pribadi siswa terhadap lingkungan antara lain: 1). pribadi yang bertanggung jawab terhadap lingkungan dan 2). perilaku yang bertanggung jawab terhadap lingkungan yang diukur dengan instrumen non-tes yang terdiri dari 45 butir pernyataan dengan pilihan jawaban, yaitu Sangat Akurat, Cukup Akurat, Akurat, Kurang Akurat, dan Tidak Akurat. Uji coba dilakukan kepada 30 partisipan dan ditemukan bahwa nilai reliabilitas instrumen tanggung jawab pribadi menggunakan rumus Cronbach's Alpha sebesar .932 .

Kuesioner tentang intensi pro-lingkungan menggunakan skala sikap yang mencirikan intensi pro-lingkungan siswa. Dimensi intensi pro-lingkungan siswa antara lain: 1). keinginan untuk melindungi lingkungan, 2). keinginan untuk melestarikan lingkungan, dan 3). keinginan untuk memanfaatkan sumber daya alam yang diukur dengan instrumen non-tes yang terdiri dari 54 butir pernyataan dengan pilihan jawaban, yaitu Sangat Akurat, Cukup Akurat, Akurat, Kurang Akurat, dan Ttidak Akurat. Uji coba dilakukan kepada 30 partisipan dan ditemukan bahwa nilai reliabilitas instrumen intensi pro-lingkungan menggunakan rumus Cronbach's Alpha sebesar .851.

\section{Teknik Analisis}

Analisis data penelitian untuk uji prasyarat, menggunakan uji normalitas (KolmogorovSmirnov), uji homogenitas (Levene dan Bartlett). Sementara itu, untuk uji hipotesis dilakukan uji model regresi $(\alpha=.05)$ dan uji korelasi Pearson Product Moment $(\alpha=.05)$. Analisa juga mencakup perhitungan koefisien determinasi dan kontribusi ketiga variabel tersebut. 


\section{ANALISIS DAN HASIL}

\section{Deskripsi Data}

Tabel 1 merangkum deskripsi data yang diperoleh.

Tabel 1.

Data Masing-Masing Variabel $(N=120)$

\begin{tabular}{lccc} 
& LOC & PR & PEI \\
\hline Rerata $(M)$ & 59.33 & 82.68 & 77.1 \\
Standar Deviasi $(S D)$ & 12.16 & 10.72 & 10.83 \\
Varians & 147.87 & 114.92 & 117.38 \\
Nilai Minimum & 20 & 45 & 51 \\
Nilai Maksimum & 85 & 99 & 93 \\
\hline
\end{tabular}

Keterangan: $\mathrm{LoC}=$ wilayah kendali (locus of control), $\mathrm{PR}=$ tanggung jawab pribadi (personal responsibility), $\mathrm{PEI}=$ intensi pro-lingkungan (pro-environmental intention)

\section{Analisis Korelasi}

Pertama, dilakukan uji korelasi sederhana antara wilayah kendali dan intensi pro-lingkungan dan antara tanggung jawab pribadi dan intensi pro-lingkungan. Berdasarkan perhitungan pada Tabel 2, diperoleh bahwa terdapat hubungan positif yang signifikan antara wilayah kendali dengan intensi pro-lingkungan. Tanggung jawab pribadi juga diketahui berhubungan positif dan signifikan dengan intensi pro-lingkungan.

Tabel 2.

Matriks Uji Korelasi Sederhana

\begin{tabular}{cccc}
\hline & LOC & PR & PEI \\
\hline LoC & 1 & & \\
PR & .077 & 1 & \\
PEI & $.309^{* *}$ & $.202^{*}$ & 1 \\
\hline
\end{tabular}

Keterangan: $\mathrm{LoC}=$ wilayah kendali (locus of control), $\mathrm{PR}=$ tanggung jawab pribadi (personal responsibility), $\mathrm{PEI}=$ intensi pro-lingkungan (pro-environmental intention)

${ }^{*}=$ signifikan pada taraf $.05 ;{ }^{* *}=$ signifikan pada taraf .001

Selanjutnya, dilakukan uji korelasi ganda antara wilayah kendali dan tanggung jawab pribadi dengan intensi pro-lingkungan. Hasil uji korelasi menunjukkan adanya hubungan signifikan yang positif dan signifikan antara wilayah kendali dan tanggung jawab pribadi $(r=.357 ; p=.000)$ dengan intensi pro-lingkungan. 


\section{Koefisien Determinasi dan Kontribusi}

Pada analisis selanjutnya, dilakukan perhitungan koefisien determinasi dan kontribusi wilayah kendali terhadap intensi pro-lingkungan. Dari hasil perhitungan, diperoleh nilai koefisien determinasi sebesar .095. Hasil tersebut menunjukkan bahwa wilayah kendali memberikan kontribusi terhadap intensi pro-lingkungan siswa sebesar 9.5 persen, sedangkan 90.5 persen berhubungan dengan faktor yang lain.

Selanjutnya, data hasil perhitungan mengenai kontribusi tanggung jawab pribadi dan intensi pro-lingkungan menunjukkan nilai koefisien determinasi sebesar .041. Hasil tersebut menunjukkan bahwa tanggung jawab pribadi memberikan kontribusi terhadap intensi pro-lingkungan siswa sebesar 4.1 persen, sedangkan 95.9 persen berhubungan dengan faktor yang lain.

Terakhir, kontribusi wilayah kendali dan tanggung jawab pribadi diukur secara bersamasama dan menghasilkan koefisien determinasi sebesar .127. Hasil tersebut menunjukkan bahwa wilayah kendali dan tanggung jawab pribadi secara bersama-sama memberikan kontribusi terhadap intensi pro-lingkungan siswa sebesar 12.7 persen, sedangkan 87.3 persen berhubungan dengan faktor yang lain.

\section{DISKUSI}

Penelitian ini menemukan bahwa terdapat hubungan positif yang signifikan antara wilayah kendali dengan intensi pro-lingkungan, tanggung jawab pribadi dengan intensi pro-lingkungan, dan wilayah kendali dan tanggung jawab pribadi secara bersama-sama dengan intensi pro-lingkungan.

Berdasarkan uji koefisien determinasi antara wilayah kendali dengan intensi prolingkungan, wilayah kendali memiliki kontribusi sebesar 9.5 persen kepada intensi pro-lingkungan yang berarti wilayah kendali memberikan sumbangsih sebesar 9.5 persen kepada intensi prolingkungan. Selain itu, wilayah kendali mempunyai keterkaitan terhadap intensi pro-lingkungan, di mana semakin baik wilayah kendali internal, maka semakin tinggi pula intensi pro-lingkungan siswa tersebut. Hasil tersebut didukung oleh pernyataan Weimer, Ahlström, Lisspers, dan Lipsanen (2017) yang berpendapat bahwa siswa dengan wilayah kendali internal percaya dapat mengendalikan peristiwa dalam hidup karena perilakunya ditentukan oleh faktor internal, seperti kerja keras, pengambilan keputusan, keterampilan pemecahan masalah, upaya, dan persuasi. Contohnya, saat siswa melihat sampah di lingkungan sekolahnya, jika terdapat dua keputusan antara membuang sampah tersebut ke tempat sampah dan mengabaikan sampah tersebut, siswa 
dengan wilayah kendali internal akan memilih untuk berusaha membuang sampah tersebut dibanding mengabaikan dan menyerahkan ke orang lain untuk membuang sampah tersebut.

Siswa dengan wilayah kendali internal cenderung memandang dan menyakini peritistiwa yang terjadi di lingkungan disebabkan oleh tindakannya tersebut, sehingga keinginan dan perilaku siswa tersebut lebih bertanggung jawab terhadap lingkungan. Hasil penelitian ini relevan dengan temuan Yang, Lin, dan Liu (2016), yaitu terdapat hubungan yang signifikan antara wilayah kendali dan keinginan untuk bertindak. Siswa yang dapat mengontrol apa yang sedang terjadi mempunyai keinginan dan perilaku yang lebih tinggi untuk peduli terhadap norma-norma dan nilai-nilai yang terdapat di lingkungan.

Berdasarkan uji koefisien determinasi antara tanggung jawab pribadi dengan intensi prolingkungan, ditunjukkan bahwa tanggung jawab pribadi memiliki kontribusi sebesar 4.1 persen kepada intensi pro-lingkungan yang berarti tanggung jawab pribadi memberikan sumbangsih sebesar 4.1 persen kepada intensi pro-lingkungan. Selain itu, tanggung jawab pribadi mempunyai keterkaitan terhadap intensi pro-lingkungan, di mana semakin tinggi tanggung jawab pribadi, maka semakin tinggi pula intensi pro-lingkungan siswa tersebut. Siswa yang memiliki tanggung jawab pribadi yang tinggi mampu belajar bagaimana menghormati hak dan perasaan orang lain, mampu memutuskan keinginannya sendiri, dan mengerti pentingnya bertanggung jawab. Misalnya, saat diberi tanggung jawab untuk menjaga lingkungan, maka siswa yang memiliki tanggung jawab pribadi yang tinggi akan menjaga lingkungan tersebut tetap bersih. Hasil penelitian ini relevan dengan yang dikemukakan oleh Ernst, Blood, dan Beery (2017) bahwa siswa yang mempunyai tanggung jawab pribadi yang tinggi dapat mengembangkan kepekaan terhadap orang lain (termasuk belas kasih, empati, dan keterampilan interpersonal) dan kemampuan untuk menerapkan pembelajaran di seluruh program dalam kehidupan yang lebih luas (misalnya, sekolah dan rumah). Siswa tersebut akan menerapkan pelajaran tentang pencemaran lingkungan di sekolah untuk menjaga lingkungan rumahnya tetap bersih. Siswa yang memiliki tanggung jawab pribadi yang tinggi mampu menjadi pembelajar yang mandiri, mampu memainkan peran aktif dalam pembelajaran, dan memiliki keinginan untuk lebih bertanggung jawab.

Berdasarkan uji koefisien determinasi antara wilayah kendali dan tanggung jawab pribadi secara bersama-sama dengan intensi pro-lingkungan, ditemukan bahwa wilayah kendali dan tanggung jawab pribadi memiliki kontribusi sebesar 12.7 persen kepada intensi pro-lingkungan yang berarti wilayah kendali dan tanggung jawab pribadi secara bersama-sama memberikan sumbangsih sebesar 12.7 persen kepada intensi pro-lingkungan. Ditinjau dari uji determinasi, 
kontribusi wilayah kendali dan tanggung jawab pribadi mengalami peningkatan saat bersama-sama, sehingga dapat disimpulkan bahwa wilayah kendali dan tanggung jawab pribadi mempunyai keterkaitan yang signifikan terhadap intensi pro-lingkungan, di mana semakin baik wilayah kendali internal dan semakin tinggi tanggung jawab pribadi, maka semakin tinggi pula intensi prolingkungan siswa tersebut.

Siswa dengan wilayah kendali internal cenderung mengubah perilakunya dengan mudah untuk mencapai keinginannya, di mana upaya pribadi efektif untuk mencapai hasil yang diinginkan. Siswa menunjukkan bahwa semakin banyak usaha yang dilakukan, maka keberhasilannya semakin besar. Siswa dengan wilayah kendali internal memiliki kemungkinan keberhasilan yang lebih tinggi dibandingkan dengan siswa dengan wilayah kendali eksternal yang mengandalkan nasib dan keberuntungan (Angelova, 2016). Siswa yang memiliki tanggung jawab pribadi akan menghargai keputusan yang telah dipilih beserta konsekuensinya ketika diperhadapkan dengan berbagai pilihan (Mergler, 2016).

Wilayah kendali dan tanggung jawab pribadi berkontribusi dengan intensi pro-lingkungan siswa dikarenakan faktor internal yang terdapat di dalam diri siswa yang cenderung menyakini bahwa keberhasilannya berasal dari usahanya sendiri; mereka juga memiliki tanggung jawab pribadi yang tinggi untuk menjaga lingkungan, sehingga membuatnya berkeinginan untuk peduli pada lingkungan. Dengan adanya wilayah kendali internal dan tanggung jawab pribadi, siswa percaya bahwa usaha dan tanggung jawab pada diri sendirilah yang dapat mengubah keinginanya untuk peduli terhadap lingkungan. Hasil penelitian ini relevan dengan penelitian Talens (2016) bahwa faktor kepribadian (yaitu sikap), wilayah kendali, dan tanggung jawab pribadi mempunyai hubungan yang signifikan dengan keinginan untuk bertindak, sehingga menghasilkan perilaku peduli lingkungan. Begitu pula dengan penelitian Hwang, Kim, dan Jeng (2000) yang menemukan pengaruh wilayah kendali terhadap keinginan untuk bertindak. Hasil penelitian Palupi dan Sawitri (2018) juga mengemukakan bahwa remaja yang memiliki tanggung jawab pribadi yang tinggi mempunyai keinginan yang lebih untuk peduli terhadap lingkungan. Selain itu, Rahman (2016) juga berpendapat bahwa tanggung jawab pribadi merupakan salah satu faktor yang memengaruhi keinginan seseorang untuk peduli terhadap lingkungan. 


\section{SIMPULAN DAN SARAN}

\section{Simpulan}

Penelitian ini bertujuan untuk mengetahui apakah terdapat hubungan yang signifikan antara wilayah kendali dan tanggung jawab pribadi dengan intensi pro-lingkungan pada siswa XI MIPA di SMAN 8 Makassar. Berdasarkan hasil penelitian dan pembahasan dapat disimpulkan bahwa wilayah kendali dan tanggung jawab pribadi mempunyai hubungan positif yang signifikan dengan intensi pro-lingkungan siswa XI MIPA di SMAN 8 Kota Makassar. Artinya, semakin baik wilayah kendali internal dan semakin tinggi tanggung jawab pribadi, maka semakin tinggi pula intensi prolingkungan siswa tersebut.

\section{Saran Teoretis}

Penelitian berikutnya diharapkan dapat meneliti lebih lanjut mengenai faktor-faktor yang berhubungan dengan intensi pro-lingkungan agar penelitian ini dapat dieksplorasi lebih dalam dan dapat menjadi penelitian yang lebih terbarukan, serta dapat mengubah keinginan untuk lebih peduli terhadap lingkungan.

\section{Saran Praktis}

Para guru sebaiknya memberikan stimulus yang dapat merangsang wilayah kendali dan tanggung jawab pribadi siswa agar wilayah kendali yang bersifat internal dan tanggung jawab pribadi yang dimiliki siswa semakin tinggi dan dapat meningkatkan intensi pro-lingkungan siswa tersebut. Sementara itu, para siswa diharapkan lebih berusaha dan bertanggung jawab dalam kebersihan lingkungan.

\section{REFERENSI}

Angelova, N. V. (2016). Locus of control and its relationship with some social-demographic factors. Psychological Thought, 9(2), 248-258. doi: 10.5964/psyct.v9i2.179

Arttachariya, P. (2009). Individual determinants of responsible environmental behavior. $A B A C$ Journal, 29(2), 14-23. 
Erkan, K. (2015). The relationship between locus of control and perfectionism perception of the primary school administrators. Procedia-Social and Behavioral Sciences, 174, 3893-3902. doi: 10.1016/j.sbspro.2015.01.1130

Ernst, J., Blood, N., \& Beery, T. (2017). Environmental action and student environmental leaders: Exploring the influence of environmental attitudes, locus of control, and sense of personal responsibility. Environmental Education Research, 23(22), 149-175. doi: 10.1080/13504622.2015.1068278

Ferraz, S. B., Buhamra, C., Laroche, M., \& Veloso, A. R. (2017). Green products: A cross-cultural study of attitude, intention and purchase behavior. Revista de Administração Mackenzie, 18(5), 12-38. doi: 10.1590/1678-69712017/administracao.v18n5p12-38

Fishbein, M., \& Ajzen, I. (2011). Predicting and changing behavior: The reasoned action approach. New York, NY: Psychology Press.

Henriksson, N. (2017). Fake news? Examining the connection between value-based environmental messages, environmental concern, and pro-environmental intention. Journal of Psychology and Brain Studies, 1(3), 1-8.

Hines, J. M., Hungerford, H. R., \& Tomera, A. N. (1987). Analysis and synthesis of research on responsible environmental behavior: A meta-analysis. The Journal of Environmental Education, 18(2), 1-8. doi: 10.1080/00958964.1987.9943482

Hwang, Y.-H., Kim, S.-I., \& Jeng, J.-M. (2000). Examining the causal relationships among selected antecedents of responsible environmental behavior. The Journal of Environmental Education, 31(4), 19-25. doi: 10.1080/00958960009598647

Keshavarz, M., \& Karami, E. (2016). Farmers' pro-environmental behavior under drought: Application of protection motivation theory. Journal of Arid Environments, 127, 128-136. doi: 10.1016/j.jaridenv.2015.11.010

Mergler, A. (2016). Personal responsibility: An integrative review of conceptual and measurement issues of the construct. Research Papers in Education, 32(2), 254-267. doi: 10.1080/02671522.2016.1225801

Mergler, A., \& Patton, W. (2007). Adolescents talking about personal responsibility. Journal of Student Wellbeing, 1(1), 57-70. doi: 10.21913/JSW.v1i1.113

Mergler, A., \& Shield, P. (2016). Development of the personal responsibility scale for adolescents. Journal of Adolescence, 51, 50-57. doi: 10.1016/j.adolescence.2016.05.011 
Mergler, A., Spencer, F. H., \& Patton, W. A. (2008). Personal responsibility: The creation, implementation and evaluation of a school-based program. Journal of Student Wellbeing, 2(1), 35-51.

Palupi, T., \& Sawitri, D. R. (2018). The importance of pro-environmental behavior in adolescent. E3S Web of Conferences, 31, 1-4. doi: 10.1051/e3sconf/20183109031

Pan, S., Chou, J., Morrison, A. M., Huang, W., \& Lin, M. (2018). Will the future be greener? The environmental behavioral intentions of university tourism students. Sustainability, 10(3), 117. doi: $10.3390 / \mathrm{su} 10030634$

Rahman, N. A. (2016). Knowledge, internal, and environmental factors on environmental care behaviour among aboriginal students in Malaysia. International Journal of Environmental and Science Education, 11(12), 5349-5366.

Ramdhani, N. (2011). Penyusunan alat pengukur berbasis theory of planned behavior. Buletin Psikologi, 19(2), 55-69. doi: 10.22146/bpsi.11557

Rotter, J. B. (1966). Generalized expectancies for internal versus external control of reinforcement. Psychological Monographs, 80(1), 1-28. doi: 10.1037/h0092976

Rucas, S. L., \& Miller, A. A. (2013). Locus of control and sleep in evolutionary perspective. Journal of Social, Evolutionary, and Cultural Psychology, 7(2), 79-96. doi: $10.1037 / \mathrm{h} 0099208$

Slavoljub, J., Zivkovic, L., Sladjana, A., Dragica, G., \& Zorica, P. S. (2015). To the environmental responsibility among students through developing their environmental values. ProcediaSocial and Behavioral Sciences, 171, 317-322. doi: 10.1016/j.sbspro.2015.01.128

Steg, L., \& Vlek, C. (2009). Encouraging pro-environmental behaviour: An integrative review and research agenda. Journal of Environmental Psychology, 29(3), 309-317. doi: 10.1016/j.jenvp.2008.10.004

Talens, J. D. (2016). Development and validation of Responsible Environmental Behavior Scale towards Solid Waste Management (REBS-SWM) in school setting. International Journal of Advanced Engineering, Management and Science (IJAEMS), 2(4), 191-197.

Weimer, K., Ahlström, R., Lisspers, J., \& Lipsanen, J. (2017). Values, attitudes, moral judgement competence, locus of control and sense of coherence as determinants of pro-environmental behaviors and behavioral intentions. Journal of Multidisciplinary Engineering Science and Technology (JMEST), 4(5), 2568-2583. 
Wibisono, A. F., \& Dewi, P. (2014). Sosialisasi bahaya membuang sampah sembarangan dan menentukan lokasi tpa di Dusun Deles Desa Jagonayan Kecamatan Ngablak. Jurnal Inovasi Dan Kewirausahaan, 3(1), 21-27.

Yang, J. C., Lin, Y. L., \& Liu, Y. (2016). Effects of locus of control on behavioral intention and learning performance of energy knowledge in game-based learning. Journal of Environmental Education Research, 23(6), 886-899. doi: 10.1080/13504622.2016.1214865 